\title{
Prevalence of Panton Valentine Leukocidin Gene in Methicillin Resistant and Sensitive Staphylococcus aureus Isolated from Egyptian Hospitals
}

\author{
A.K. El-Essawy ${ }^{*+}$, R.A. Roshdy ${ }^{* *}$, H.M. Abu Shady ${ }^{* * *}$ and \\ A.A. Emara* \\ "Microbiology Departments in Specialized Hospital, Ain Shams \\ University, ${ }^{* *}$ National Institute of Hepatology and Tropical \\ Medicine and ${ }^{* * *}$ Microbiology Department, Faculty of Science, \\ Ain Shams University.
}

\begin{abstract}
STAPHYLOCOCCUS aureus (S. aureus) carrying Panton-Valentine leukocidin (PVL) has become a serious global problem. PantonValentine leukocidin-positive Staphylococcus aureus can result in several infections. Although it is associated with community acquired methicillin resistant $S$. aureus (MRSA), several outbreaks due to methicillin-sensitive Staphylococcus aureus (MSSA) were reported. This study was conducted to determine the frequency of PVL-positive gene in methicillin-resistant Staphylococcus aureus (MRSA) and methicillin-sensitive Staphylococcus aureus (MSSA) among isolates from Egyptian hospitals.

Various clinical samples were collected from two Egyptian hospitals, one in Cairo and the other in Zagazig Governorates. The samples were collected from January 2010 to December 2010 and subjected to culture then bacterial identification. S. aureus was identified by conventional methods then MRSA and MSSA isolates were identified using sensitivity test for both oxacillin and cefoxitin and the results were compared with Chrom ID MRSA (Chromogenic media for detection of MRSA). Polymerase chain reaction (PCR) was used to detect the PVL gene among 42 MRSA and 25 MSSA isolates.

Among PCR tested isolates, $11.9 \%$ of $S$. aureus isolates harbored the PVL gene (8/67). Five MRSA isolates were harboring the gene representing also $11.9 \%$ (5/42). Three among 25 MSSA isolates were PVL positive (12\%). Accordingly, no significant difference was observed between MRSA and MSSA regarding the presence of the PVL gene. On the other hand, no PVL gene was detected among 10 Gram positive isolates other than $S$. aureus (3 of them were coagulase negative Staphylococci).
\end{abstract}

Staphylococcus aureus (S. aureus) is one of the major human pathogens that can cause community and hospital-acquired (HA) infections (Fey et al., 2003). This bacterium is the most prevalent isolate taken from hospitalized patients.

${ }^{+}$Corresponding author: aymankama199@hotmail.com 
The global emergence of methicillin-resistant Staphylococcus aureus (MRSA) has turned into a serious public health problem. The bacterium is known as the most significant cause of nosocomial infections, which are resistant to different antibacterial classes. Antibiotic therapy has faced severe difficulties due to these strains (David et al., 2006 and Holmes et al., 2005).

The pathogenesis of $S$. aureus is caused by several virulence factors such as staphylococcal exoproteins (Gravet $e$ t al., 1998). Among the exotoxins produced by $S$. aureus, some can selectively destroy phagocyte cells such as polymorphonuclear cells and monocytes. These exotoxins belong to the bi-component leukotoxin family, including S and F proteins. Panton-Valentine leukocidin (PVL) is a member of the staphylococcus leukotoxin family (Choorit et al., 1995; Kaneko et al., 1997 and Havaei et al., 2010). It is a very important virulence factor in S. aureus, which is a pore-forming exotoxin and its toxic effects result from the synergistic performance of 2 separate proteins (LUK S-PV and LUK F-PV) (Supersac et al., 1993 and Ruimy et al., 2008).

Staphylococcus aureus strains containing the PVL gene have the potential to epidemiologically spread in the community (Hollis et al., 1995). In fact, the PVL gene was first reported among community-acquired (CA) MRSA strains (Miller et al., 2005).

CA-MRSA strains are more likely to produce PVL (Supersac et al., 1993), but some studies refer to the prevalence of PVL-containing $S$. aureus isolates from the community to the hospital (O'Brien et al., 1999), this is a remarkable risk to public health. Moreover, the analysis of MRSA isolates in Holland (2003) showed that 8\% of nosocomial isolates carry locus for PVL (Wannet et al., 2004). Therefore, the isolates do not only exist in communities but can also spread in hospitals (Wagenlehner et al., 2007). Consequently, early diagnosis and decolonizing carriers is inevitable and essential, since it can prevent person-to-person transmission of the isolates and, ultimately, fatal prevalence (Munckhof et al., 2009).

In the current study, the prevalence of PVL gene was determined using PCR technique among $S$. aureus isolated from clinical samples in two Egyptian hospitals. The isolates were identified as MRSA or MSSA.

\section{Material and Methods}

\section{Patient and sampling}

The samples were collected from out patients and inpatients departments, (Intensive Care Unit, orthopedic) at Zagazig University hospitals, Egypt and from Kobbri El-Kobba Military Hospital in Cairo. The samples collected from January 2010 to December 2010. These cases were suffering urinary tract infection, cutaneous abscesses, wounds infection, pneumonia, furunculosis and several necrotic infections. These samples included mainly pus, urine, blood and sputum.

Egypt. J. Bot., 55, No. 1 (2015) 


\section{Bacterial cultivation and isolation}

The collected samples were cultivated on Blood agar, Deoxyribonuclease, Mannitol salt agar and Meuller Hinton agar.

\section{Bacterial Identification}

A. Morphology and microscopy: Colonies were examined for morphology and Gram positive grape-like clusters of staphylococci (Kloos and Bannerman, 1995).

B. Biochemical reactions: Catalase test, tube and slide coagulase test, mannitol salt agar and deoxyribonuclease test were performed.

\section{Antibiotic susceptibility test}

Disc diffusion method : Sensitivity of the isolated strains to oxicillin $(1 \mu \mathrm{g})$ and cefoxitin $(30 \mu \mathrm{g})$ was performed on Meuller Hinton agar plates.

\section{Chrom ID MRSA}

The bacterial isolates were subjected to culture on a chromogenic media for detection of MRSA.

Multiplex polymerase chain reaction $(P C R)$

The primers (GeneBank accession no. AB245454) were designed according to Taneike et al. (2006) and Motoshima et al. (2010). The primer for the luk-PV gene that encoding Panton- Valentine Leucocidin is the forward primer GTG ATC GCG CTG AGG TAG TG and the reverse primer CCT CCT GTT GAT GGA CCA CT. PCR reaction was performed according to the following steps:

A. Dream Taq Green PCR Master Mix (2x) was gently vortexed and briefly centrifuged after throwing.

B. A thin-walled PCR tube was placed on ice and the following components were added for each $50 \mu 1$ reaction:

\begin{tabular}{|l|c|}
\hline Dream Taq green PCR Master Mix $(\mathbf{2 x})$ & $\mathbf{2 5} \boldsymbol{\mu l}$ \\
\hline Forward primer & $0.5 \mu \mathrm{M}$ \\
\hline Reverse Primer & $0.5 \mu \mathrm{M}$ \\
\hline Template DNA & $1 \mu \mathrm{g}$ \\
\hline Water, nuclease free & To $50 \mu \mathrm{l}$ \\
\hline Total volume & $50 \mu \mathrm{l}$ \\
\hline
\end{tabular}

C. Samples were gently vortexed \& spin down.

D. Thermal cycling conditions of PCR reaction were as follows:

\begin{tabular}{|l|c|c|c|}
\hline \multicolumn{1}{|c|}{ Steps } & Temp. ${ }^{\circ} \mathbf{c}$ & Time & \multirow{2}{*}{ No. of cycles } \\
\hline Initial denaturation & 94 & $3 \mathrm{~min}$ & 1 \\
\hline Denaturation & 95 & $30 \mathrm{sec}$. & \multirow{2}{*}{30} \\
\cline { 1 - 3 } Annealing & 54 & $30 \mathrm{sec}$. & \\
\cline { 1 - 3 } Automated Florescent extension & 72 & $1 \mathrm{~min}$. & \\
\cline { 1 - 2 } Final extension & 72 & $5 \mathrm{~min}$ & 1 \\
\hline
\end{tabular}


E. Five $\mu$ l of PCR product was loaded directly on agarose gel using DNA Ladder. (Taneike et al., 2006).

\section{Statistical analysis}

Data analysis was performed using Chi-squared test, Fisher's exact test and T-test.

\section{Results}

Table 1. shows the distribution of MRSA and MSSA among different types of specimens with no statistically significant difference.

Five out of 8 PVL carrying $S$. aureus isolates were MRSA and ten non $S$. aureus isolates were negative for the PVL gene, 3 of them were coagulase negative Staphylococci. The prevalence of the PVL gene among MRSA and MSSA isolates (Table 2) and different age of patients (Table 3), shows no significant difference. On the other hand among the 8 PVL strains, 7 were isolated from males, none from females and 1 without recovered gender, revealing a significant differnce(Table 6).

TABLE 1. Distribution of MRSA and MSSA isolated from different samples.

\begin{tabular}{|l|c|c|c|c|}
\hline \multirow{2}{*}{ Types of samples } & \multicolumn{2}{|c|}{ MRSA isolates } & \multicolumn{2}{c|}{ MSSA isolates } \\
\cline { 2 - 5 } & Number/ Total & \% & Number/ Total & \% \\
\hline Urine & $5 / 8$ & 62.5 & $3 / 8$ & 37.5 \\
\hline Pus & $30 / 49$ & 61.2 & $19 / 49$ & 38.8 \\
\hline Blood & $3 / 4$ & 75 & $1 / 4$ & 25 \\
\hline Peritoneal Fluid & $0 / 1$ & 0 & $1 / 1$ & 100 \\
\hline Sputum & $1 / 1$ & 100 & $0 / 1$ & 0 \\
\hline Sinusitis Fluid & $0 / 1$ & 0 & $1 / 1$ & 100 \\
\hline Pleural Fluid & $1 / 1$ & 100 & $0 / 1$ & 0 \\
\hline Not Reported & $2 / 2$ & 100 & $0 / 2$ & 0 \\
\hline
\end{tabular}

$* \mathrm{P}>0.05$ as comparison for all specimen types.

TABLE 2. Prevalence of PVL gene among MRSA \& MSSA isolates.

\begin{tabular}{|l|c|c|}
\hline \multirow{2}{*}{ AMONG ISOLATES } & $\begin{array}{c}\text { PVL } \\
\text { ISOLATES/TOTAL }\end{array}$ & PERCENT \\
\hline MRSA & $5 / 42$ & $11.9 \%$ \\
\hline MSSA & $3 / 25$ & $12 \%$ \\
\hline Total $S$.aureus & $8 / 67$ & $11.9 \%$ \\
\hline
\end{tabular}

TABLE 3. Patients' age among PVL harboring isolates.

\begin{tabular}{|l|c|c|}
\hline Isolates & Age Mean \pm SD & P value \\
\hline PVL positive & $26.1 \pm 13.2$ & \multirow{2}{*}{$>0.05$} \\
\hline PVL negative & $38.3 \pm 18.1$ & \\
\hline
\end{tabular}

The type of sample shows no statistical association with the detection of the PVL gene in the isolated S. aureus strains (Table 4). However, 5 out of 8 PVL

Egypt. J. Bot., 55, No. 1 (2015) 
carrying isolates were from pus samples. Among the 8 PVL gene carrying strains, there were five isolates from different wounds or abscesses, one from blood infection and one from lung infection (pleural fluid) (Table 5).

TABLE 4. Detected PVL gene among different types of samples.

\begin{tabular}{|l|c|c|c|c|}
\hline \multirow{2}{*}{ Types of samples } & \multicolumn{2}{|c|}{ PVL negative isolates } & \multicolumn{2}{c|}{ PVL positive isolates } \\
\cline { 2 - 5 } & Number/ Total & $\%$ & Number/ Total & $\%$ \\
\hline Urine & $8 / 8$ & 100 & $0 / 8$ & 0 \\
\hline Pus & $44 / 49$ & 89.8 & $5 / 49$ & 10.2 \\
\hline Blood & $3 / 4$ & 75 & $1 / 4$ & 25 \\
\hline Peritoneal Fluid & $1 / 1$ & 100 & $0 / 1$ & 0 \\
\hline Sputum & $1 / 1$ & 100 & $0 / 1$ & 0 \\
\hline Sinusitis Fluid & $1 / 1$ & 100 & $0 / 1$ & 0 \\
\hline Pleural Fluid & $0 / 1$ & 0 & $1 / 1$ & 100 \\
\hline Not Reported & $1 / 2$ & 50 & $1 / 2$ & 50 \\
\hline
\end{tabular}

TABLE 5. Sources of the isolates carrying the detected PVL gene.

\begin{tabular}{|c|c|c|c|c|c|c|c|c|}
\hline Isolate & $\mathbf{2}$ & $\mathbf{5}$ & $\mathbf{1 1}$ & $\mathbf{2 0}$ & $\mathbf{2 5}$ & $\mathbf{3 4}$ & $\mathbf{3 7}$ & $\mathbf{7 8}$ \\
\hline Specimen & Pus & Pus & Pus & Blood & $\begin{array}{c}\text { Pleura } \\
\text { l fluid }\end{array}$ & Pus & Pus & NR \\
\hline Source & $\begin{array}{c}\text { Abscess } \\
\text { after } \\
\text { appendicitis }\end{array}$ & $\begin{array}{c}\text { Abdominal } \\
\text { infection } \\
\text { after } \\
\text { surgery }\end{array}$ & $\begin{array}{c}\text { Foot } \\
\text { wound }\end{array}$ & Blood & $\begin{array}{c}\text { Pleural } \\
\text { fluid }\end{array}$ & $\begin{array}{c}\text { wound } \\
\text { infection }\end{array}$ & $\begin{array}{c}\text { wound } \\
\text { infection }\end{array}$ & NR \\
\hline
\end{tabular}

TABLE 6. Patients' gender of PVL positive isolates.

\begin{tabular}{|l|c|c|l|}
\hline Isolates & \multicolumn{2}{|c|}{ Number/Total (\%) } & \multirow{2}{*}{ P value } \\
\hline & Male & Female & \\
\cline { 1 - 3 } PVL positive & $7 / 38(18.4 \%)$ & $0 / 27(0 \%)$ & \multirow{2}{*}{$<0.05$} \\
\hline PVL negative & $31 / 38(81.6 \%)$ & $27 / 27(100 \%)$ & \\
\hline
\end{tabular}

Tables 7 and 8. show that among 42 isolates reported as MRSA by the conventional sensitivity tests (for oxacillin and cefoxitin), only 27 isolates were recognized as MRSA by the Chrom ID MRSA test. This figure shows a high significant difference between the two methods that the Chrome ID MRSA test shows a specificity of $96 \%$ and sensitivity of $64.3 \%$ respectively.

Figure 1. Gel electrophoresis images of the PCR products for the PVL gene. Eight isolates were shown to be positive for PVL gene and gave a band at $352 \mathrm{bp}$. First lane, molecular size marker and the second lane, positive control (a standard strain NCTC 13300). 
A

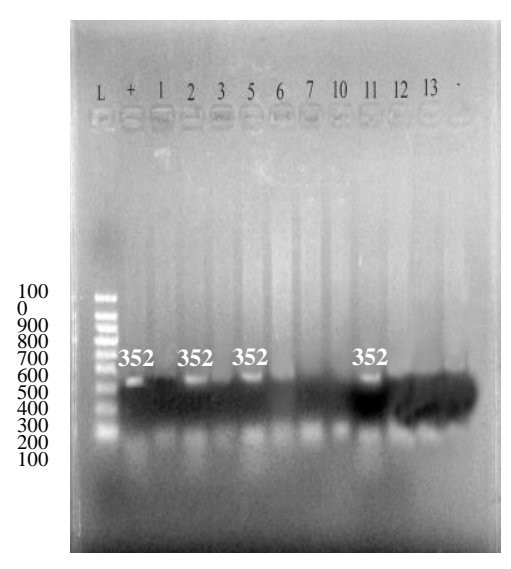

$\mathrm{C}$

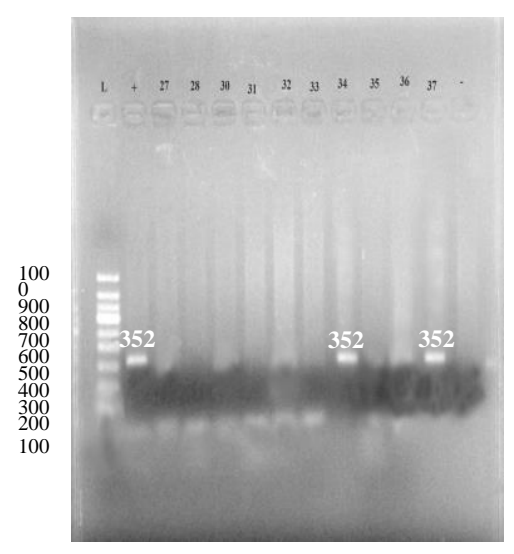

B

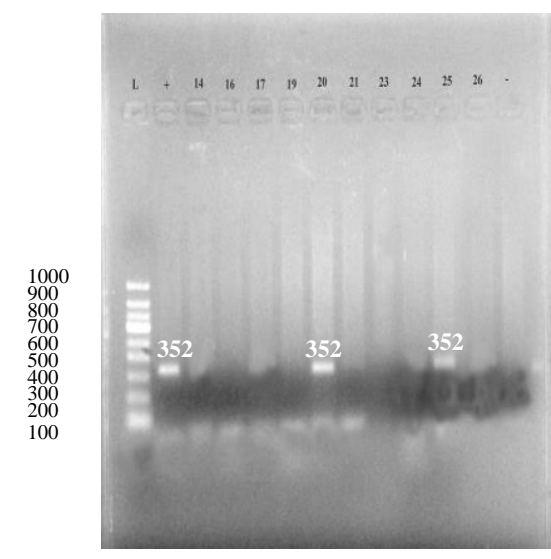

$\mathrm{D}$

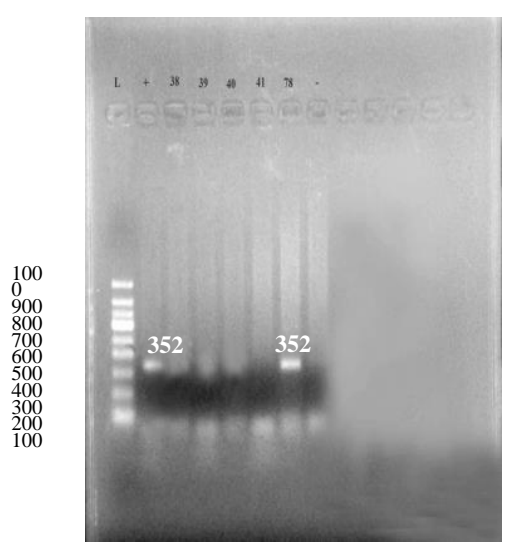

Fig. 1. Detected bands of PVL as shown on agarose gel electrophoresis of the PCR products for different bacterial isolates.

A. Lane 1: molecular size marker \& lane 2: Positive PVL gene carrier strain (a standard strain NCTC 13300) \& Lane 13: negative control (water) \& Lanes 4, 6, 10: PVL gene positive isolates number $2,5 \& 11$, other lanes: negative PVL gene isolates.

B. Lane 1: molecular size marker \& lane 2: Positive PVL gene carrier strain (a standard strain NCTC 13300) \& Lane 13: negative control (water) \& Lanes 7, 11: PVL gene positive isolates number 20, 25 \& other lanes: negative PVL gene isolates.

C. Lane 1: molecular size marker \& lane 2: Positive PVL gene carrier strain (a standard strain NCTC 13300) \& Lane 13: negative control (water) \& Lanes 9, 13: PVL gene positive isolates number $34,37 \&$ other lanes: negative PVL gene isolates.

D. Lane 1: molecular size marker \& lane 2: Positive PVL gene carrier strain (a standard strain NCTC 13300) \& Lane 8: negative control (water) \& Lane 7: PVL gene positive isolate number $78 \&$ other lanes: negative PVL gene isolates.

Egypt. J. Bot., 55, No. 1 (2015) 
TABLE 7. Detection of MRSA by conventional antibiotic sensitivity and chrome ID MRSA tests.

\begin{tabular}{|l|c|c|c|}
\hline \multirow{2}{*}{ Isolates } & \multicolumn{2}{|c|}{ Number/Total (\%) } & \multirow{2}{*}{ P value } \\
\cline { 2 - 3 } & By Antibiotic Sensitivity & By Chrome ID MRSA & \multirow{2}{*}{$<0.001$} \\
\hline MRSA & $42 / 67(62.7 \%)$ & $28 / 67(41.8 \%)$ & \\
\hline
\end{tabular}

TABLE 8. Sensitivity and specificity of the chrome ID MRSA test as compared to antibiotic sensitivity.

\begin{tabular}{|c|c|c|c|c|}
\hline \multirow{2}{*}{\multicolumn{2}{|c|}{ aim }} & \multicolumn{2}{|c|}{$\begin{array}{c}\text { Number of isolates by } \\
\text { Chrome ID MRSA }\end{array}$} & \multirow[t]{2}{*}{ Total } \\
\hline & & MRSA & MSSA & \\
\hline \multirow{2}{*}{$\begin{array}{l}\text { Number of isolates by } \\
\text { antibiotic Sensitivity }\end{array}$} & MRSA & 27 & 15 & 42 \\
\hline & MSSA & 1 & 24 & 25 \\
\hline \multicolumn{2}{|l|}{ Totals } & 28 & 39 & 67 \\
\hline \multicolumn{2}{|c|}{ Sensitivity of Chrome ID MRSA } & \multicolumn{3}{|c|}{$64.3 \%$} \\
\hline \multicolumn{2}{|c|}{ Specificity of Chrome ID MRSA } & \multicolumn{3}{|c|}{$96 \%$} \\
\hline
\end{tabular}

\section{Discussion}

Panton-Valentine leukocidin (PVL) is a cytotoxin produced by Staphylococcus aureus that causes leukocyte destruction and tissue necrosis (Genestier et al., 2005). Although produced by $<5 \%$ of S. aureus strains according to some studies, the toxin is detected in large percentages of isolates that cause necrotic skin lesions and severe necrotizing pneumonia (Lina et al., 1999). It is commonly associated with community-acquired methicillin resistant S. aureus (CA-MRSA) (Vandenesch et al., 2003). However, several outbreaks due to methicillin susceptible $S$. aureus (MSSA) have also been reported (Boubaker et al., 2004 ; Österlund et al., 2002 and Le Thomas et al., 2001).

The prevalence of the PVL gene among MRSA, MSSA and all S. aureus isolated in this study, showed similar percentages (around 12\%). This agreed with a study reporting that the rate of MSSA harboring the PVL gene was (11.3\%) (Shallcross et al., 2009). While, the prevalence of the PVL gene is estimated to be some $2-35 \%$ among MRSA strains as previously reported by other studies (Santucci et al., 2003 and Melles et al., 2004). Previous reports indicated that PVL is produced by $<5 \%$ of $S$. aureus strains (Lina et al., 1999). On the other hand, Azar et al. (2012) showed that the prevalence of the PVL gene in MRSA strains was (7.23\%), while this prevalence was (33.3\%) for in MSSA strains. Another study shows that the prevalence of PVL-positive MRSA was $10.7 \%$ and among PVL-positive isolates $75 \%$ were MRSA (6 MRSA out of 8 PVL-positive) (Solmaz et al., 2012), which is close to our study as 5 out of 8 PVL positive isolates were MRSA $(63 \%)$. A recent Indonesian study reported that $1.5 \%$ of the studied patients carried Panton-Valentine leukocidin (PVL)positive methicillin-sensitive S. aureus (MSSA) (Santosaningsih et al., 2014). 
However, the differences in the rate of prevalence are possibly due to different geographical areas and the type of assay used to diagnose the gene.

The age of patients had no significant effect on the prevalence of PVL according to the current study. Similarly, data analysis of Azar et al. (2012) who studied isolates from burns, revealed that there was no significant correlation between the presences of genes mecA, PVL and patients' age or degree of burn (P> 0.5). Lopez-Aguilar et al. (2007) also showed no significant effect of patient age. However, Shallcross et al. (2010) reported that compared to individuals aged $<20$ years, the odds of PVL-SA-related infection were highest in subjects aged $20-39$ years and reduced thereafter with increasing age (OR 3.2, 95\% CI 1.1-8.7, p 0.02).

On the other hand the 7 PVL isolates in this study were from males and not from females and 1 without recorded gender with a statistically significant difference. The higher prevalence of PVL in isolates from males is not clearly explained but the relative activity of males and possible exposure to different types of injuries and community infections may provide a possible explanation especially since most of these isolates were from wounds. Although, LopezAguilar et al. (2007) showed no statistically significant effect of patient gender, the 5 PVL positive isolates were exclusively from males while PVL negative isolates were 12 were males and 7 were from females. On the other hand Shallcross et al. (2010) showed that men had approximately twice the odds compared to women of having PVL-S. aureus-related disease.

The type of sample shows no statistical association with detection of the PVL gene in the isolated S. aureus strains. However, 5 out of 8 PVL carrying isolates were from pus samples. Among the 8 PVL gene carrying strains, there were five isolates from different wounds or abscesses, one from blood infection and one from lung infection (Pleural fluid). Gerard et al. (1999) reported that a collection of 172 S. aureus strains were screened for PVL genes by polymerase chain reaction amplification. PVL genes were detected in $93 \%$ of strains associated with furunculosis and in $85 \%$ of those associated with severe necrotic hemorrhagic pneumonia (all community-acquired). They were detected in $55 \%$ of cellulitis strains, $50 \%$ of cutaneous abscess strains, $23 \%$ of osteomyelitis strains, and $13 \%$ of fingerpulp-infection strains. PVL genes were not detected in strains responsible for other infections, such as infective endocarditis, mediastinitis, hospital-acquired pneumonia, urinary tract infection, and enterocolitis, or in those associated with toxic-shock syndrome. It thus appears that PVL is mainly associated with necrotic lesions involving the skin or mucosa. Solmaz et al. (2012) reported that out of 56 isolates, $14.3 \%$ were PVL positive with $37.5 \%$ were from abscess and $62.5 \%$ from wound. Among all of these isolates $67.8 \%$ were MRSA.

It is noted in various reports that a patient with abscess or recurrent furuncle should be primarily suspected of PVL related S. aureus infection (Department of health, 2007). Shallcross et al. (2010) showed that PVL-SA infection was strongly associated with skin and soft tissue disease and these samples were four-

Egypt. J. Bot., 55, No. 1 (2015) 
fold more likely to contain the PVL genes compared to all other sample types. Didisheim et al. (2014) reported 3 cases of osteoarticular infections by S. aureus PVL positive sensitive to methicilline, which illustrates the difficulties encountered in the management and treatment, as well as the potential for serious orthopedical complications.

Accurate and rapid detection of methicillin-resistant Staphylococcus aureus is very important in a clinical laboratory setting to avoid treatment failure. Velasco et al. (2005) stated that in the absence of availability of molecular biology techniques, the cefoxitin disc was the best predictor of methicillin resistance in $S$. aureus among the techniques tested. Other authors also reported that the results of cefoxitin disc diffusion test one in concordance with the PCR for mecA gene and give better results compared to the oxacillin disc diffusion method. Thus, cefoxitin disc diffusion test can be an alternative to PCR for detection of MRSA in resource constraint settings (Anand et al., 2009). However, Adaleti et al. (2008) compared conventional methods (oxacillin agar screening (OAS), oxacillin disc diffusion (ODD) and cefoxitin disc diffusion (CDD) methods) against the gold standard polymerase chain reaction (PCR) technique to determine the best combination of the routine procedures. They concluded that combining the ODD and CDD methods could be a good choice for detecting methicillin resistance in $S$. aureus strains where mecA PCR cannot be performed. By consideration of this report, combining the ODD and CDD methods was used in the current study to identify MRSA strains.

The current study shows that among 42 isolates reported as MRSA by the conventional sensitivity tests (for oxacillin and cefoxitin), only 27 isolates recognized as MRSA by few Chrom ID MRSA test. This figure shows a high were significant difference between the two methods and shows sensitivity and specificity of Chrom ID MRSA of $64.3 \%$ and $96 \%$ respectively as compared to antibiotic sensitivity methods. These results disagree with other reports by Kumar et al. (2013) who stated that the MRSA ID chromogenic medium has a sensitivity of $96 \%$ and a specificity of $99.5 \%$ after $24 \mathrm{hr}$ of incubation but it compared to PCR as a gold standard. This variation in specificity may (in addition to the different gold standard reference methods) due to cultivation conditions such as incubation time as Van Vaerenbergh et al. (2010) compared two chromogenic media for the detection of MRSA: BBL CHROMagar MRSA II (BD) and MRSA ID agar (bioMe'rieux). After $24 \mathrm{hr}$, the sensitivities of both media were high and comparable. Both media showed an important decrease in specificity after $48 \mathrm{hr}$ of incubation (decreases of $8 \%$ for MRSA II and 10\% for MRSA ID), but MRSA II was significantly more specific at both time points.

PVL- carrying isolates do not only exist in communities but can also spread in hospitals (Wagenlehner et al., 2007). To counter this emerging global threat to Public health, systematic surveillance of both hospital and community isolates is required, together with measures designed to limit their spread. Consequently, early diagnosis and decolonizing carriers is inevitable and essential, since it can prevent person-to-person transmission of the isolates. In suspected cases, PVL 
and MRSA detection could be included in one panel for rapid response to the detected isolates. Such panel could be a multiplex PCR for PVL and mecA genes.

\section{References}

Adaleti, R. Nakipoglu, Y., Karahan, C.Z.. Tasdemir, C. and Kaya, F. (2008) Comparison of polymerase chain reaction and conventional methods in detecting methicillin-resistant Staphylococcus aureus. J. Infect. Developing Countries, 2: 46-50.

Anand, K.B.. Agrawal, P.. Kumar, S. and Kapila, K. (2009) Comparison of cefoxitin disc diffusion test, oxacillin screen agar, and PCR for mecA gene for detection of MRSA. Indian Journal of Medical Microbiology., 27: 27-9.

Azar, D.K. Hajar, H. and Zahra, F. (2012) The prevalence of genes encoding leukocidins in Staphylococcus aureus strains resistant and sensitive to methicillin isolated from burn patients in Taleghani hospital, Ahvaz, Iran., 38: 247-251.

Boubaker, K., Diebold, P., Blanc, D.S., Vandenesch, F., Praz, G. and Dupuis G. (2004) Panton-Valentine leukocidin and staphylococcal skin infections in schoolchildren. Emerg Infect Dis., 10:121-4.

Choorit, W., Kaneko, J. and Muramoto, K. (1995) Existence of a new protein component with the same function as the LukF component of leukocidin or gammahemolysin and its gene in Staphylococcus aureus P83. FEBS Lett., 357: 260-264.

David, M.Z., Crawford, S.E. and Boyle-Vavra, S. (2006) Contrasting pediatric and adult methicillin-resistant Staphylococcus aureus isolates. Emerg Infect Dis., 12: 631637.

David, V., Tomas, M, d-M. Cartelle, M., Beceiro, A., Perez, A., Molina, F., Moure, R., Villanueva, R. and Bou, G. (2005) Evaluation of different methods for detecting methicillin (oxacillin) resistance in Staphylococcus aureus, Journal of Antimicrobial Chemotherapy., 55: 379-382.

Department of health (2007) Interim guidance on diagnosis and management of PVLassociated staphylococcal infections in the UK. Clin Infect., 22: 118-26.

Didisheim, C., Dubois-Ferrière, V., Dhouib, A., Lascombes, P., Cherkaoui, A., Renzi, G., François, P., Schrenzel, J. and Ceroni, D. (2014) Severe osteoarticular infections with Staphylococcus aureus producer of Panton-Valentine Leukocidine in children. Rev. Med. Suisse., 10(416):355-9.

Fey, P.D., Saïd-Salim, B. and Rupp, M.E. (2003) Comparative molecular analysis of community- or hospital-acquired methicillin-resistant Staphylococcus aureus. Antimicrob Agents Chemother., 47:196-203.

Genestier, A.L., Michalete, M.C., Prévoset, G., Bellot, G., Chalabreysse, L. and Peyrol, S. (2005) Staphylococcus aureus Panton-Valentine leukocidin directly targets mitochondria and induces Bax-independent apoptosis of human neutrophils. J. Clin Invest., 115: 3117-27.

Egypt. J. Bot., 55, No. 1 (2015) 
Gerard, L., Yves, P'm. Florence, G.G., Miche'le, B., Peter, M.O. Gauduchon, V., Vandenesch, F. and Etienne, J. (1999) Involvement of Panton-Valentine leukocidinproducing Staphylococcus aureus in primary skin infections and pneumonia. Clinical Infectious Diseases, 29:1128-32.

Gravet, A., Colin, D.A. and Keller, D. (1998) Characterization of a novel structural member, LukE-LukD, of the bi-component staphylococcal leucotoxins family. FEBS Lett., 436: 202-208.

Havaei, S.A., Ohadian Moghadam, S. and Pourmand, M.R. (2010) Prevalence of genes encoding bi-component leukocidins among clinical isolates of methicillinresistant Staphylococcus aureus. Iranian J. Publ Health., 39: 8-14.

Hollis, R.J., Barr, J.L. and Doebbeling, B.N. (1995) Familial carriage of methicillinresistant Staphylococcus aureus and subsequent infection in a premature neonate. Clin. Infect. Dis., 21:328-332.

Holmes, A., Ganner, M. and McGuane, S. (2005) Staphylococcus aureus isolates carrying Panton-Valentine leucocidin genes in England and Wales: Frequency, characterization and association with clinical disease. J. Clin. Microbiol., 43:23842390 .

Kaneko, J., Muramoto, K. and Kamio, Y. (1997) Gene of LukF-PV-like component of Panton-Valentine leukocidin in Staphylococcus aureus P83 is linked with lukM. Biosci Biotechnol Biochem., 61: 541-544.

Kloos, W.E. and Bannerman, T.L. (1995) Staphylococcus and micrococcus, In: "Manual of Clinical Microbiology", Murray, P.R., Baron, E.J., Pfaller, M.A., Tenover, F.C., Yolken, R.H., (Ed.), 282-298, ASM press, ISBN 13: 978-1555811266, Washington DC.

Kumar, V.A., Steffy, K., Chatterjee, M., Madhan, S., Kavitha, R.D., Anand, M., Shamsul, K. and Raja, B. (2013) Detection of oxacillin-Susceptible mecA-positive Staphylococcus aureus isolates by use of chromogenic medium MRSA ID. Journal of Clinical Microbiology., 51:318-319.

Le Thomas, I., Mariani-Kurkdjian, P., Collignon, A., Gravet, A., Clermont, O. and Brahimi, N. (2001) Breast milk transmission of a Panton-Valentine leukocidinproducing Staphylococcus aureus strain causing infantile pneumonia. J. Clin. Microbiol. 39:728-9.

Lina, G., Piémont, Y., Godail-Gamot, F., Bes, M., Peter, M.O. and Gauduchon, V. (1999) Involvement of Panton-Valentine leukocidin-producing Staphylococcus aureus in primary skin infections and pneumonia. Clin. Infect. Dis., 29:1128-32.

Lopez-Aguilar, C., Perez-Roth, E., Mendez-Alvarez, S., Moreno, A., Duran, M.C., Casanova, C. and Aguirre-Jaime, A. (2007) Association between the Presence of the Panton-Valentine leukocidin-encoding gene and a lower rate of survival among hospitalized pulmonary patients with staphylococcal disease. J. Clin. Microbiol., 45: 274-276. 
Maiko, M., Katsunori, Y., Yoshitomo, M., Junichi, M., Kazuyuki, S., Yasuaki, Y., Shigeru, K. and Shimeru, K. (2010) Genetic diagnosis of community-acquired mrsa: a multiplex real- time pcr method for staphylococcal cassette chromosome mec typing and detecting toxin genes. Tohoku J. Exp. Med., 220: 165- 170.

Melles, D.C., Gorkin, R.F., Boelen, H.A. and Snijder, S. (2004) Natura populatio dynami an expansio of pathogeni clone of Staphylococcu aureus. Cli. Invest., 114(12): 1732-40.

Miller, L.G., Perdreau-Remingto, F. and Rie, G. (2005) Necrotizin fasciiti cause by community- associated methicillin- resistant Staphylococcu aureu i. Lo. Angeles Eng. Med., 352:1445-1453.

Motoshima, M., Yanagihara, K. and Morinaga, Y. (2010) Genetic diagnosis of community-acquired MRSA: a multiplex real-time PCR method for staphylococcal cassette chromosome mec typing and detecting toxin genes. Tohoku J. Exp. Med., 220: $165-170$.

Munckhof, W.J., Nimm, G.R. and Schooneveld, J.M. (2009) Nasal carriage of Staphylococcus aureus including community-associate methicillin-resistant strains in Queenslan adults. Cli. Microbio. Infect., 15:149-155.

O'Brien, F.G., Pearman, J.W. and Gracey, M. (1999) Community strains of methicillin-resistant Staphylococcus aureus involved in hospital outbreak. Cli. Microbiol., 37: 2858-2862.

Österlund, A., Kahlmeter, G., Bieber, L., Runehagen, A. and Breider, J.M. (2002) Intrafamilial spread of highly virulent Staphylococcus aureus strains carrying the gene for Panton-Valentin leukocidin Scand. J. Infect Dis., 34:763-87.

Pourman, M.R., Memarian, M. and Hosein, M. (2009) High prevalence of sea gene among clinical isolates of Staphylococcus aureus in Tehran. AMI 47:357-361.

Ruimy, R. Maiga, A. and Armand-Lefevre, L. (2008) The carriage population of Staphylococcus aureus from Mali is composed of a combination of pandemic clones and the divergent Panton-Valentine leukocidin-positive genotype ST152. J. Bacteriol., 190: $3962-3968$.

Santosaningsih, D., Santoso, S., Budayanti, N.S., Kuntaman, K., Lestari, E.S., Farida, H., Hapsari, R., Hadi, P., Winarto, W., Milheiriço, C., Maquelin, K., WillemseErix, D., van Belkum, A., Severin, J.A. and Verbrugh, H,A. (2014) Epidemiology of Staphylococcus aureus harboring the mecA or Panton-Valentine leukocidin genes in Hospitals in Java and Bali, Indonesia. Am. J. Trop. Med. Hyg., 90:728-34.

Santucci, Z., Gobara, S., Santos, R., Fontany, C. and Levin, Z. (2003) Infections in a burn intensive care unit: experience of seven years. J. Hosp Infect., 53(1): 6-13.

Shallcross, L.J., Williams, K., Hopkins, S., Aldridge, R.W., Johnson, A.M. and Hayward, A.C. (2010) Panton-Valentine leukocidin associated staphylococcal disease: a cross-sectional study at a London hospital, England. Clin. Microbiol Infect., 16: $1644-1648$.

Egypt. J. Bot., 55, No. 1 (2015) 
Solmaz, O.M., Seyed, A.H. and Mohammad, R.P. (2012) Prevalence of MethicillinResistant Staphylococcus aureus carrying Panton-Valentine leukocidin gene in cutaneous Infections in the City of Isfahan, J. Med. Bacteriol., 1:9-16.

Supersac, G., Prevost, G. and Piemont, Y. (1993) Sequencing of leucocidin R from Staphylococcus aureus P83 suggests that staphylococcal leucocidins and gammahemolysin are members of a single, two-component family of toxins. Infect. Immun., 61:580-587.

Supersac, G., Prevost, G. and Piemont, Y. (1993) Sequencing of leucocidin R from Staphylococcus aureus P83 suggests that staphylococcal leucocidins and gammahemolysin are members of a single, two-component family of toxins. Infect. Immun., 61:580-587.

Taneike, I., Taketo, O., Soshi, D., Kohei, S., Kyoko, O., Misao, T., Wataru, H., Tomomi, T. and Tatsuo, Y. (2006) Molecular nature of methicillin- resistant Staphylococcus aureus derived from explosive nosocomial outbreaks of the 1980 in Japan. FEBS Letters, 580, 2323-2334.

Van Vaerenbergh, K., Cartuyvels, R., Coppens, G., Frans, J., Van den Abeele, A.M. and De Beenhouwer, H. (2010) On behalf of the BILULU Group. Performance of a new chromogenic medium, BBL CHROMagar II (BD), for detection of methicillinresistant Staphylococcus aureus in screening samples. Journal of Clinical Microbiology, 48: 1450-1451.

Vandenesch, F., Naimi, T., Enright, M.C., Lina, G., Nimma, G.R. and Heffernan, H. (2003) Community-acquired methicillin-resistant Staphylococcus aureus carrying Panton-Valentine leukocidin genes: worldwide emergence. Emerg. Infect. Dis., 9:97884.

Velasco, D., Tomas, M., Cartelle, M., Beceiro, A., Perez, A., Molina, F., Moure, R.,Villanueva, R. and Bou, G. (2005) Evaluation of different methods for detecting methicillin (Oxacillin) resistance in Staphylococcus aureus.J. Antimicrob Chemother, 55, 379-382.

Wagenlehner, F.M. Naber, K.G. and Bambl, E. (2007) Management of a large healthcare-associated outbreak of Panton-Valentine leucocidin-positive meticillinresistant Staphylococcus aureus in Germany. J. Hosp. Infect., 67:114-120.

Wannet, W.J. Heck, M.E. and Pluister, G.N. (2004) Panton-Valentine leukocidin positive MRSA in 2003: The Dutch situation. Euro Surveill., 9: 28-29.

(Received 20/ 5/2014;

accepted 27/10/2014) 


\section{دراسة على عزلات إكلينيكية من ستافيلوكوكس اوريوس الثرسة

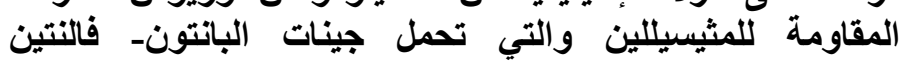 لوكوسيدين}

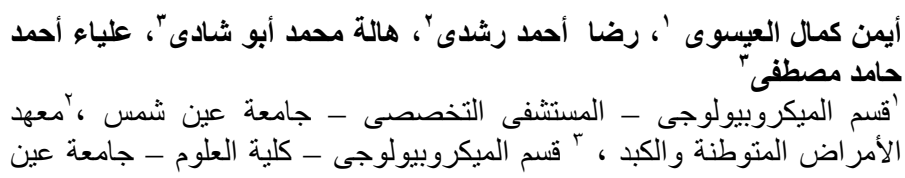

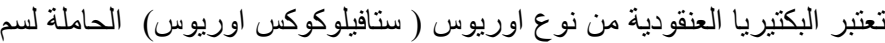

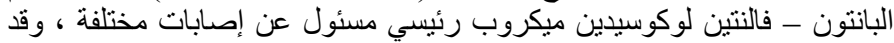

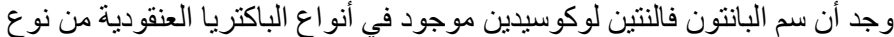

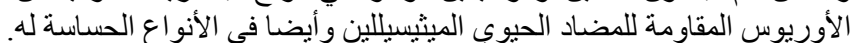

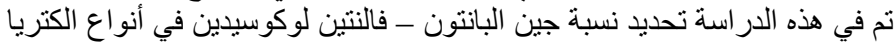

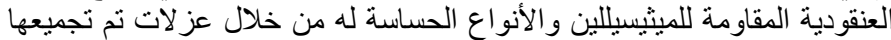
من المستشفيات المصرية.

تم تجميع عزلات الستافيلوكوكس من مرضى من مستشفى كوبري القبة مئة

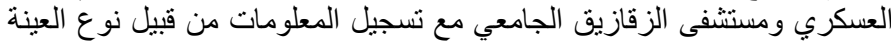

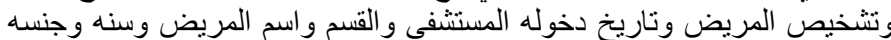

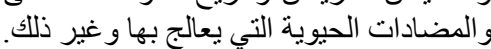

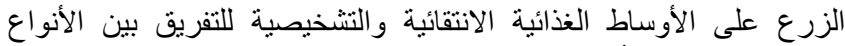

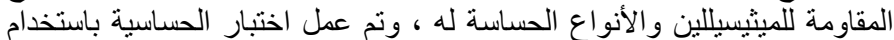

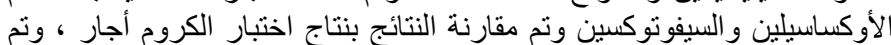
الكثف عن جينات البانتون فالنتين لوكوسيدين باستين باستخدام طريقة تفاعل البلمرة

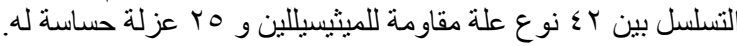

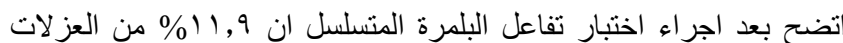

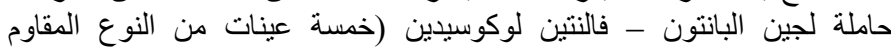

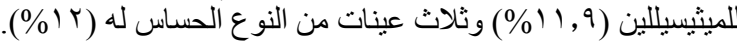

